\title{
Larval settlement rates and gene flow of broadcast- spawning (Acropora tenuis) and planula-brooding (Stylophora pistillata) corals
}

\author{
Akira Nishikawa ${ }^{1,3,4, *}$, Masaya Katoh ${ }^{2}$, Kazuhiko Sakai ${ }^{3}$ \\ ${ }^{1}$ Marine Environmental Science, Department of Chemistry, Biology and Marine Science, University of the Ryukyus, \\ Nishihara, Okinawa 903-0213, Japan \\ ${ }^{2}$ Seikai National Fisheries Research Institute, Fisheries Research Agency, Fukai-Ohta 148-446, Ishigaki, Okinawa 907-0451, Japan \\ ${ }^{3}$ Sesoko Station, Tropical Biosphere Research Center, University of the Ryukyus, 3422 Sesoko, Motobu, Okinawa 905-0227, Japan \\ ${ }^{4}$ Present address: Sesoko Station, Tropical Biosphere Research Center, University of the Ryukyus, 3422 Sesoko, Motobu, \\ Okinawa 905-0227, Japan
}

\begin{abstract}
Larval settlement rates, genetic structure, and gene flow of broadcast-spawning (Acropora tenuis) and planula-brooding (Stylophora pistillata) corals (Scleractinia) were compared within a $500 \mathrm{~km}$ range in the Ryukyu Archipelago. We conducted a laboratory experiment to investigate planula settlement rates, and a broad sampling survey to determine genetic variation in both species in the Archipelago. In the laboratory experiment, the planulae of $S$. pistillata settled a few hours after release, while those of $A$. tenuis started to settle at least $4 \mathrm{~d}$ after the release of gametes. The survival rates and competency periods of larvae were higher and longer for A. tenuis than for S. pistillata. These results suggest that broader dispersal is more likely for $A$. tenuis than for $S$. pistillata. In the population genetic analysis, we measured local (2 stations in a region) and regional (Okinawa, Kerama and Yaeyama) patterns of genetic variation with allozyme electrophoresis. We also inferred the levels of gene flow in the 2 species. In the study area, gene flow $\left(N_{\mathrm{e}} m\right)$ and genetic distance $(D)$ were, respectively, higher and smaller for the spawner $A$. tenuis $\left(N_{\mathrm{e}} m=3.5\right.$ to $16.4, D=0.028$ to 0.187$)$ than for the brooder $S$. pistillata $\left(N_{\mathrm{e}} m=0.9\right.$ to $1.5, D=0.026$ to 0.309$)$. Therefore, the planulae settlement rates were well in agreement with gene flow. In addition, for both species, $N_{\mathrm{e}} m$ between the Okinawa and Kerama regions (30 to $150 \mathrm{~km}$ apart; $N_{\mathrm{e}} m=9.4$ to $22.5 \mathrm{in} A$. tenuis and 1.4 to 3.3 in $S$. pistillata) was higher than that between the Okinawa-Kerama and Yaeyama regions (up to $500 \mathrm{~km}$ apart; $N_{\mathrm{e}} m=3.1$ to 9.4 in $A$. tenuis and 0.5 to 1.4 in $S$. pistillata). The results suggest that coral populations in the Kerama Island are a major source of the coral planulae needed for the recovery of both brooding and spawning coral communities around the Okinawa Islands, after the mass-bleaching event in 1998.
\end{abstract}

KEY WORDS: Scleractinian coral · Reproductive mode $\cdot$ Competency $\cdot$ Gene flow $\cdot$ Larvae source Ryukyu Archipelago

Resale or republication not permitted without written consent of the publisher

\section{INTRODUCTION}

The degree of genetic differentiation and the level of gene flow among local populations of benthic marine invertebrates may vary among species according to the dispersal potential of larvae. In scleractinian corals, the mode of sexual reproduction, i.e. broadcast- spawning versus planula-brooding, may influence the dispersal potential of their larvae (reviewed in Harrison \& Wallace 1990). While brooded planulae generally settle within a few hours of release (Atoda 1947, Harrigan 1972, Richmond 1987a, Harrison \& Wallace 1990), planulae originating from spawning require 4 to $6 \mathrm{~d}$ after gamete release before they settle (Hodgson 
1985, Babcock \& Heyward 1986, Harrison \& Wallace 1990). This suggests that the dispersal potential of brooded planula is more restricted than that of planulae originating from spawning, because of the shorter pre-competency period in brooders versus spawners. Nevertheless, a previous comprehensive study of the population genetics of scleractinian corals does not fully support this hypothesis. Ayre \& Hughes (2000) studied the population genetics of 5 brooding and 4 spawning coral species on the Great Barrier Reef (GBR) of Australia. They estimated that, in 3 of the 5 brooding species and all of the spawning species, larval dispersal was sufficient to maintain moderate to high levels of gene flow along the entire GBR. In contrast, they estimated that local populations of the remaining 2 brooding species (Stylophora pistillata and Seriatopora hystrix) were genetically more weakly connected than the other 7 species.

In addition to the pre-competency period, the competency period of planulae also affects the dispersal distance of coral planulae (Harrigan 1972, Richmond 1987a, Harrison \& Wallace 1990). Laboratory investigations of larval competency in corals show that the planulae of both spawners and brooders may continue in the planktonic phase for many weeks if no substrate is available (Richmond 1987a, Morse \& Morse 1991, Morse et al. 1996, Wilson \& Harrison 1998). Moreover, the duration of the planktonic phase differs among species, even among those with the same reproductive mode. For spawning species, Wilson \& Harrison (1998) studied the competency periods of 3 coral species in the GBR. They reported that competency periods ranged from $26 \mathrm{~d}$ for Cyphastrea serailia to $56 \mathrm{~d}$ for Goniastrea australensis and $78 \mathrm{~d}$ for Acanthastrea lordhowensis. For brooding species, Richmond (1987a) and Harii et al. (2002) showed that the competency period of planulae of Pocillopora damicornis exceeded $100 \mathrm{~d}$ in the Marshall Islands and the Ryukyu Archipelago (hereafter called the 'Ryukyus'). Harii et al. (2002) also showed that the competency period of Heliopora coerulea was $30 \mathrm{~d}$ in the Ryukyus. Therefore, the dichotomy of spawner versus brooder does not always account for the differences in the competency periods of coral planulae.

Characteristics related to sexual reproduction, including the competency period of the larval phase, may vary over the geographic range for the same coral species. For example, Sakai (1997) found that the massive coral Goniastrea aspera brooded planulae after spawning by retaining some eggs within its polyps; these brooded planulae could settle soon after release in the Ryukyus. In contrast, G. aspera in the GBR is known only as a spawner (Babcock 1984, Babcock et al. 1986). Hence, the larval dispersal distance of the Ryukyus and GBR G. aspera might differ if other con- ditions (such as the current regime) are the same, due to the different reproductive modes of $G$. aspera in the Ryukyus and those in the GBR. Moreover, the lifehistory traits of Pocillopora damicornis also vary greatly among regions of the Indo-Pacific. In the eastern Pacific, large clones of $P$. damicornis spread vegetatively through rapid growth and fragmentation, and larval recruitment is relatively uncommon. In contrast, in the western and central Pacific, colonies grow less rapidly, are generally smaller and produce fewer fragments, and larval recruits are highly abundant (Richmond $1987 \mathrm{~b}$ ). In population genetic studies of $P$. damicornis, the level of genetic differentiation was very different between Western Australia (Adjeroud \& Tsuchiya 1999) and the Ryukyus (Stoddart 1984) Wright's fixation index $\left(F_{\mathrm{ST}}=0.213\right.$ and 0.056 , respectively) even on similar geographic scales (400 and $500 \mathrm{~km}$, respectively). It is obvious, therefore, that both larval ecology and population genetics should be examined within the same region.

In this study, we compare the larval settlement rate of a spawning and a brooding coral in laboratory experiments. We have used hierarchical surveys of variation at polymorphic allozyme loci in the corals to (1) quantify local and regional patterns of genetic variation along the Ryukyus, and (2) infer gene flow within and among island groups of the Ryukyus. Based on the data for gene flow among and within the regions, we infer the geographical range of the meta-population structure of these corals in the Ryukyus.

\section{MATERIALS AND METHODS}

Although the reefs of Okinawa Islands were devastated by bleaching in 1998 (e.g. Loya et al. 2001), we were able to use Acropora tenuis and Stylophora pistillata as a representative spawner and brooder, respectively. These were both common species in the Ryukyus before the bleaching event.

Collection. We collected 6 mature colonies of Acropora tenuis (20 to $30 \mathrm{~cm}$ in diameter) on 14 June 2000 , $3 \mathrm{~d}$ before full moon, from Bise on the west coast of Okinawa Island. These were carefully transferred to an outdoor holding-tank $(2.0 \times 1.0 \times 3.5 \mathrm{~m})$ with a running (unfiltered) seawater supply at Sesoko Station, Tropical Biosphere Research Center (TBRC). After sunset each day, each colony was transferred separately to a bucket (28 $\mathrm{cm}$ diameter, $14 \mathrm{~cm}$ deep) filled with seawater. Spawning occurred during the night of 22 June. After spawning, we mixed eggs and sperm from at least 2 colonies to allow cross-fertilization. Fertilized eggs were held following the methods of Heyward \& Babcock (1986). Briefly, the eggs were put into five 11 plastic bottles filled with seawater. The density 
of the larvae in the bottles ranged from 8000 to 17000 $\mathrm{l}^{-1}$. Seawater was exchanged by squeezing the bottle in seawater; a $200 \mu \mathrm{m}$ plankton net stretched over the mouth of the bottle ensured that no fertilized eggs were lost. Approximately 30000 normally developed A. tenuis were obtained $2 \mathrm{~d}$ after gamete release, and 60 of these were measured.

For Stylophora pistillata, we collected 10 mature colonies (10 to $20 \mathrm{~cm}$ in diameter) on 5 June from Yagaji, Okinawa Islands (Fig. 1). Each colony was held separately in a plastic bucket $(30 \mathrm{~cm}$ in diameter, $15 \mathrm{~cm}$ deep) supplied with running (unfiltered) seawater at TBRC. Overflow (including larvae) from the bucket was collected in a plastic collector fitted with a plankton net (200 $\mu \mathrm{m}$ mesh). Planulation occurred mainly around 02:00 h, and larvae were collected hourly during the rest of the night. Each colony released up to 200 larvae a night. We obtained 2509 S. pistillata planulae between 9 and 13 June 2000, and 60 of these were measured.

Survival. The planulae of Acropora tenuis and Stylophora pistillata were reared separately in glass bottles (18 cm diameter, $23 \mathrm{~cm}$ in height) with seawater previously filtered through a $100 \mu \mathrm{m}$ plankton net, 1000 planulae per bottle for A. tenuis, 400 per bottle for $S$. pistillata (the total number of larvae collected was much lower for $S$. pistillata). Aeration was provided to keep the planulae suspended in the bottles. The bottles were placed in outdoor holding-tanks supplied with running seawater (at half the bottle height) to minimize temperature changes and provide natural illumination; 3 replicates were run for each species. The seawater in the bottles was replaced every $3 \mathrm{~d}$ and the temperature in the bottles varied from 26 to $30^{\circ} \mathrm{C}$ during the experiment. The experiment for $A$. tenuis was started on 24 June, that for $S$. pistillata on 11 June. The surviving planulae in each bottle were counted using a stereoscopic microscope, once a week for $A$. tenuis and once every $2 \mathrm{~d}$ in the first week and then every 2 or $3 \mathrm{~d}$ after the first week for $S$. pistillata. Survival rate was based on the initial number of planulae in the respective bottles. Since we found zooxanthellae-infected larvae $35 \mathrm{~d}$ after the release of gametes for $A$. tenuis, we also counted them together with surviving larvae once weekly, beginning $38 \mathrm{~d}$ after the release of gametes. Observations were continued until the number of surviving planulae had decreased to $10 \%$ of the initial number.

Settlement. Using larvae cultured with the same method as for the survival experiment, but in other glass bottles, we determined the settlement rates of planulae. Although both metamorphosed and attached planulae (Acropora tenuis) were observed, settlement was determined by counting metamorphosed planulae. The cultured planulae were put into small plastic aquaria $(15 \times 20 \times 13 \mathrm{~cm})$ filled with seawater filtered through a $100 \mu \mathrm{m}$ plankton net. A terracotta tile $(10 \times$ $10 \times 2 \mathrm{~cm}$ ) with a rough surface was placed on the bottom of each aquarium as settlement substrate, and elevated $1 \mathrm{~cm}$ above the bottom by small plastic tubes at the corners. The tiles had been conditioned in the sea for a month before the experiment, and any macroinvertebrates on their surface were removed with a soft brush. The cultured planulae were released into the small aquaria after 3 culture periods (CPs) of increasing length for both species: 2,30 and $60 \mathrm{~d}$ after the gamete release for Acropora tenuis; 0, 20 and $40 \mathrm{~d}$ after planulae release for Stylophora pistillata. There were 3 eplicates for each CP (i.e. 9 replicates per species). The number of planulae ranged from 80 to 300 for $A$. tenuis and from 6 to 20 for $S$. pistillata per settlement aquaria. Using a stereoscopic microscope, settled planulae on the entire surface of all tiles were counted daily for planula released after the 1st CP, and once every 3 $\mathrm{d}$ after the 2nd and 3rd CPs. The tiles were carefully transferred to small containers containing seawater at the same temperature, and the settled planulae were counted and then gently returned to their culture tank. We continued the experiment until all planulae settled or died.

Allozyme electrophoresis. We established 3 geographic sampling regions (Okinawa, Kerama and Yaeyama), and collected coral samples from 2 reefs more than $5 \mathrm{~km}$ apart within each region (Fig. 1). Fragments were taken from 14 to 50 colonies that were haphazardly selected at each reef. Collected fragments were stored at $-80^{\circ} \mathrm{C}$ until electrophoresis.

Variation at polymorphic loci was determined by electrophoresis following the methods of Selander et al. (1971) and Hillis et al. (1996) using horizontal starch gels (11 to $12 \%$ ). For Acropora tenuis 4 enzyme systems were used: malate dehydrogenase $\left(M d h_{\text {; }}\right.$ EC.1.1.1.37), phosphoglucomutase (Pgm; EC.5.4.2.2), hexokinase ( $H k_{i}$ EC.2.7.1.1), and peptidase using leucyl-tyrosine ( $L t_{i}$ EC.3.4.11); for Stylophora pistillata 6 enzyme systems were used: $M d h, P g m, H k, L t$, peptidase using leucyl-glycyl-glycine as a substrate $\left(L g g_{i}\right.$ EC.3.4.11), and peptidase using valyl-leucine $\left(V l_{i}\right.$ EC.3.4.11/13). For Mdh, Pgm and Hk electrophoresis was conducted using Tris EDTA citrate ( $\mathrm{pH} 7.5)$ buffer, and for Lgg, Lt and Vl Tris citrate $(\mathrm{pH} 8.0)$ or Tris borate EDTA (pH 8.4) buffer at 100 to $180 \mathrm{~V}$ and 20 to $36 \mathrm{~mA}$ for 6 to $9 \mathrm{~h}$.

Statistical analysis. Allele frequencies, measures of genetic variability, and genetic differentiation among populations were analyzed using the computer program TFPGA (Tools For Population Genetic Analysis 1.3: a Windows program, http://bioweb.usu.edu/mpmbio/ available from M.P. Miller). We also assessed the magnitude and direction of departures from Hardy-Wein- 


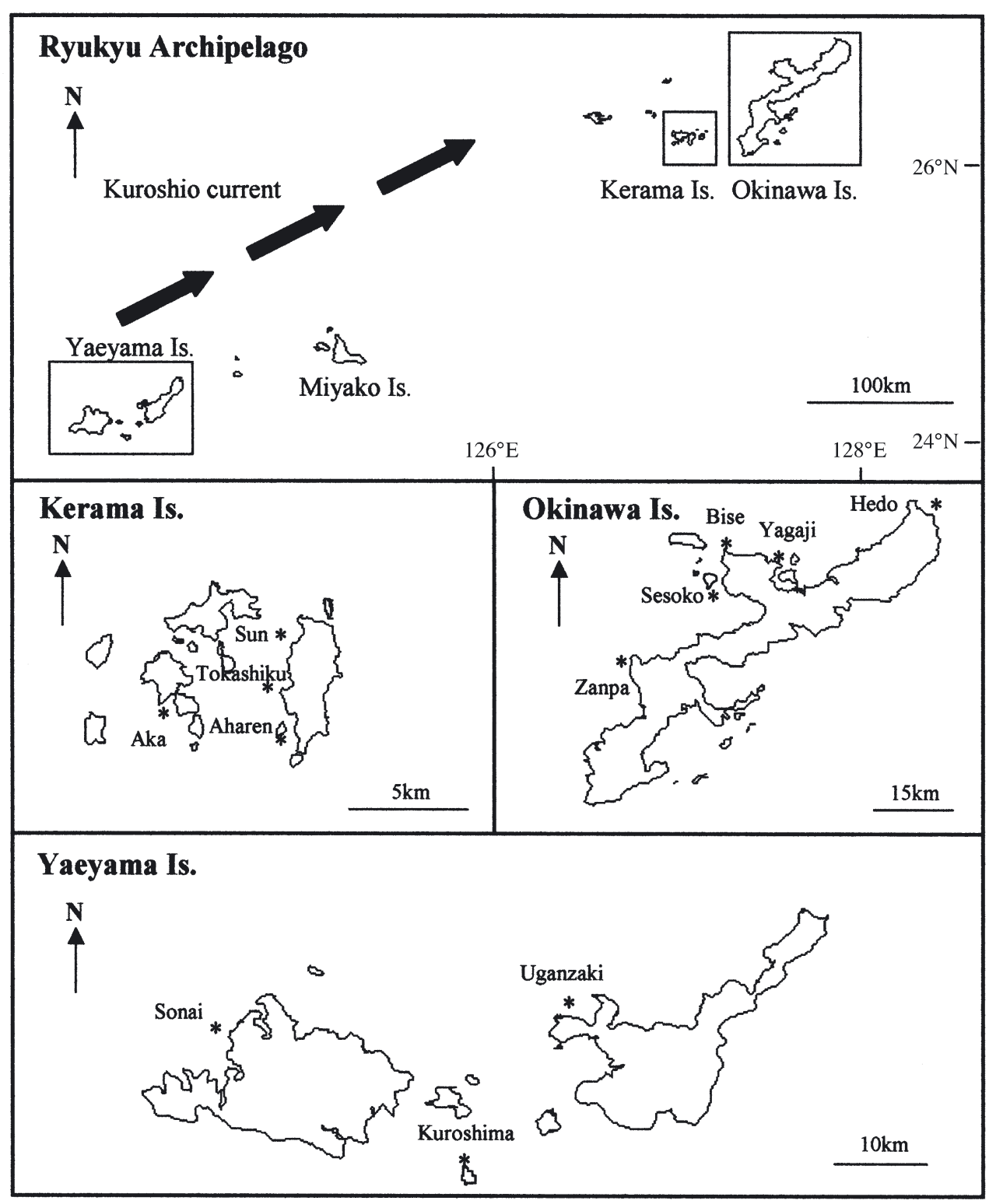

Fig. 1. Ryukyu Archipelago, showing 3 study regions (*: collection sites). Okinawa Island: Acropora tenuis collected from Hedo and Zanpa, Stylophora pistillata from Yagaji and Sesoko, mature colonies of A. tenuis from Bise; Kerama Island: A. tenuis from Tokashiku and Aka, S. pistillata from Sun and Aharen; Yaeyama Island A. tenuis from Uganzaki and Kuroshima, S. pistillata from Uganzaki and Sonai. Arrows indicate flow of Kuroshio Current

berg equilibrium. The hypothesis that each population is in Hardy-Weinberg equilibrium was tested for each locus with the conventional Monte Carlo method using TFPGA.

To assess the possible effects of asexually derived recruits on the genotypic diversity of collections we used 2 measures. (1) Each colony was assigned a multilocus (clonal) genotype. The number of multilocus genotypes detected $\left(N_{\mathrm{G}}\right)$ is an estimate of the minimum number of clones present within a population; and the ratio $N_{\mathrm{G}}: N$ (number of individual colonies collected) provides a simple index of the effect of asexual reproduction on genotypic diversity. (2) The ratio of observed multilocus genotypic diversity $\left(G_{0}\right)$ to that expected under conditions of sexual reproduction $\left(G_{\mathrm{E}}\right)$ was calculated following Stoddart \& Taylor (1988). Departure of $G_{\mathrm{O}}: G_{\mathrm{E}}$ from unity is an index of the combined effect of departures from single-locus HardyWeinberg equilibrium and multilocus linkage disequilibrium. A genetically variable population with high levels of asexual recruitment should have a low ratio of observed to expected genotypic diversity. We 
also tested for significant differences between $G_{\mathrm{O}}$ and $G_{\mathrm{E}}$ by using an unpaired $t$-test (Stoddart \& Taylor 1988).

To quantify the levels of population subdivision, we used a hierarchical analysis of the standardized genetic variance $(F)$ statistics (Wright 1969) to partition genetic variation within and among reefs. We calculated these parameters as Weir \& Cockerham's (1984) $\theta$, using the TFPGA program, which executes numerical resampling (jackknifing) to provide estimates of variance for each locus and to provide estimates of variances across loci (bootstrapping). Significant departures from $H_{\mathrm{o}}: F_{\mathrm{ST}}=0$ were evaluated using $95 \%$ confidence intervals generated by bootstrapping over each locus. We estimated the $F_{\mathrm{ST}}$ between each the 2 regions and among all 3 regions for 3 levels of the hierarchy variation: reefs within region, all regions, and all reefs. Cluster analysis was performed, and a dendrogram based on unbiased genetic distance (Nei 1978) was conducted using the UPGMA. We also estimated gene flow using Wright's (1969) island model $\left(N_{\mathrm{e}} m=\left[(1 /(\theta)-1] / 4\right.\right.$, where $N_{\mathrm{e}}$ is the effective population size and $m$ the proportion of migrants per generation).

\section{RESULTS}

\section{Larval experiments}

The mean diameter of fully developed planulae was significantly smaller in the spawning coral Acropora tenuis $(500 \pm 70 \mu \mathrm{m}, \mathrm{n}=60)$ than in the brooding coral Stylophora pistillata $(1500 \pm 200 \mu \mathrm{m}$, mean $\pm \mathrm{SE}, \mathrm{n}=60$; 2 -sample $t$-test, $\mathrm{p}<0.0001)$. In $S$. pistillata, planulae larvae already had zooxanthellae when they were released, while $A$. tenuis eggs did not contain any zooxanthellae when they were released; $35 \mathrm{~d}$ after spawning, some of the cultured $A$. tenuis planulae had acquired zooxanthellae, and these increased in number over time (A.N. \& K.S. unpubl.), with $61.4 \pm 0.08 \%$ (mean $\pm \mathrm{SD}, \mathrm{n}=225$ ) of surviving larvae containing zooxanthellae $59 \mathrm{~d}$ after spawning.

The survival rate of planulae $10 \mathrm{~d}$ after their release was about 60 and $50 \%$ of initially number of larvae in Acropora tenuis and Stylophora pistillata, respectively (Fig. 2a,b). After this period, the survival rate decreased faster in S. pistillata than in A. tenuis. In S. pistillata, (a)

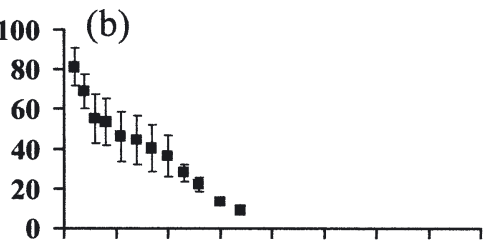

(c) $\square$ 1st CP $\triangle$ 2nd CP o 3rd CP (d)

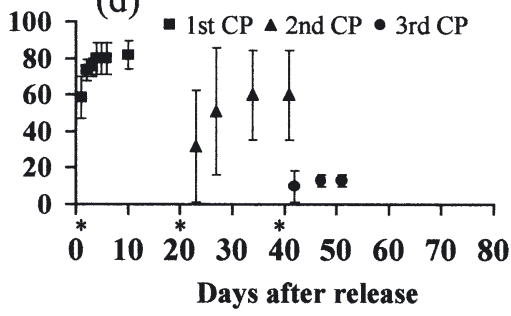

Fig. 2. (a-c) Acropora tenuis (spawner), (b-d) Stylopholla pistillata (brooder). (a) (b) Mean $( \pm \mathrm{SD})$ survival rate and $(\mathrm{c}-\mathrm{d})$ mean $( \pm \mathrm{SD})$ cumulative settlement rate $\%$ of initial planulae settled on each observation date) of coral larvae. For planulae exposed at $30 \mathrm{~d}$, final settlement at $41 \mathrm{~d}$; 3rd CP planulae ed to settlement substrate $0 \mathrm{~d}$ after planulae release, final settlemula occurred at $10 \mathrm{~d}_{;}$2nd CP planulae exposed at 20, final settlement at $41 \mathrm{~d} ; 3 \mathrm{rd}$ d at $40 \mathrm{~d}$, final settlement at $51 \mathrm{~d} . \mathrm{N}=$
Asterisks indicate respective $\mathrm{CP}$ days

the survival rate fell below 10\% (based on initially number of larvae) $33 \mathrm{~d}$ after planulae release, while it did not fall below $10 \%$ until $59 \mathrm{~d}$ after spawning in $A$. tenuis. Overall, the survival rate differed significantly between the 2 species (Log rank test, $\mathrm{p}<0.05$ ).

For the first CP in Acropora tenuis, planulae settlement was first observed on the 4th day, and the peak settlement rate was $31.7 \%$ on the 7 th day after gamete release (data not shown). Attached planulae were first observed $3 \mathrm{~d}$ after gamete release in A. tenuis. In Stylophora pistillata, the peak settlement rate was $58.3 \%$ on the first day after planulae release (Fig. 2d). In addition, we observed settled planulae a few hours after release when we were collecting planulae.

The mean cumulative settlement rate of Acropora tenuis decreased, but not significantly, from the 1st to 3rd CP (Fig. 2c: ANOVA, p > 0.05; $64.2 \pm 5.9 \%, 57.2$ $\pm 3.5 \%$, and $47.1 \pm 12.5 \%$ for the $1 \mathrm{st}, 2 \mathrm{nd}$, and $3 \mathrm{rd}$

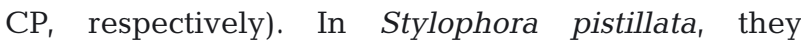
decreased significantly from the 1st to 3rd CP (Fig. 2d: ANOVA and Bartlett test, $\mathrm{p}<0.01 ; 81.7 \pm$ $7.6 \%, 59.9 \pm 24.8 \%$, and $13.1 \pm 3.4 \%$ for the $1 \mathrm{st}, 2 \mathrm{nd}$, and 3rd CP, respectively). Although the mean cumulative settlement rate of the 1st CP was significantly higher in $S$. pistillata than in A. tenuis (ANOVA, $\mathrm{p}<0.05$ ), it did not differ significantly between the 2 species for the 2nd CP (2-sample $t$-test, $\mathrm{p}>0.05)$. For the 3rd $\mathrm{CP}$, the mean cumulative settlement rate was 
Table 1. Acropora tenuis and Stylophora pistillata. Genetic variability in 6 reefs in the Ryukyu Archipelago (Fig. 1). N: no. of samples; $\mathrm{P}_{95}$ : \% of polymorphic loci at $95 \% \mathrm{CI}_{i} N_{\mathrm{G}} / N_{\mathrm{I}}$ : ratio no. of observed genotypes to no. of individuals sampled; $G_{\mathrm{O}} / G_{\mathrm{E}}:$ ratio of observed to expected genetic diversity

\begin{tabular}{|c|c|c|c|c|c|c|c|c|}
\hline \multirow[t]{2}{*}{ Locality } & \multirow[t]{2}{*}{ Code } & \multirow[t]{2}{*}{$\mathrm{N}$} & \multirow{2}{*}{$\begin{array}{l}\text { Mean no. of alleles } \\
\text { per locus }\end{array}$} & \multirow[t]{2}{*}{$\mathrm{P}_{95}$} & \multicolumn{2}{|c|}{ Mean (SD) heterozygosity } & \multirow[t]{2}{*}{$N_{\mathrm{G}} / N_{\mathrm{I}}$} & \multirow[t]{2}{*}{$G_{\mathrm{O}} / G_{\mathrm{E}}$} \\
\hline & & & & & Observed & Expected & & \\
\hline \multicolumn{9}{|c|}{ Acropora tenuis (spawner) } \\
\hline Hedo & HED & 19 & 2.8 & 100.0 & $0.240(0.168)$ & $0.496(0.134)$ & 0.95 & 0.95 \\
\hline Zanpa & $\mathrm{ZAN}$ & 23 & 3.6 & 100.0 & $0.357(0.218)$ & $0.482(0.168)$ & 0.94 & 0.92 \\
\hline Aka & AKA & 32 & 3.0 & 100.0 & $0.411(0.198)$ & $0.541(0.128)$ & 1.00 & 1.03 \\
\hline Tokashiku & TOK & 47 & 3.6 & 100.0 & $0.401(0.132)$ & $0.555(0.094)$ & 0.98 & 1.02 \\
\hline Uganzaki & UGA & 28 & 3.4 & 100.0 & $0.377(0.117)$ & $0.524(0.105)$ & 0.97 & 0.97 \\
\hline Kuroshima & KUR & 37 & 4.2 & 100.0 & $0.318(0.155)$ & $0.566(0.099)$ & 1.00 & 1.05 \\
\hline Mean & & & 3.5 & 100.0 & & & 0.97 & 0.99 \\
\hline \multicolumn{9}{|c|}{ Stylophora pistillata (brooder) } \\
\hline Yagaji & YAG & 45 & 2.4 & 71.4 & $0.225(0.184)$ & $0.301(0.218)$ & 0.87 & 0.78 \\
\hline Sesoko & SES & 16 & 1.6 & 42.9 & $0.196(0.307)$ & $0.185(0.268)$ & 0.56 & $0.44^{* * *}$ \\
\hline Sun & SUN & 37 & 2.0 & 57.1 & $0.209(0.218)$ & $0.214(0.217)$ & 0.58 & 0.77 \\
\hline Aharen & AHA & 49 & 2.1 & 57.1 & $0.213(0.252)$ & $0.222(0.215)$ & 0.51 & $0.54^{* * *}$ \\
\hline Uganzaki & UGA & 18 & 2.1 & 71.4 & $0.270(0.239)$ & $0.271(0.230)$ & 0.94 & 0.92 \\
\hline Sonai & SON & 14 & 1.7 & 42.9 & $0.235(0.354)$ & $0.202(0.237)$ & 0.57 & $0.48^{* *}$ \\
\hline Mean & & & 2.0 & 57.1 & & & 0.67 & 0.66 \\
\hline
\end{tabular}

Table 2. Acropora tenuis. Allele frequency on 6 reefs in the Ryukyu Archipelago. Collection sites abbreviated as in Table 1. Values in parentheses: no. of individuals

\begin{tabular}{|c|c|c|c|c|c|c|c|}
\hline \multirow[t]{2}{*}{ Locus } & \multirow[t]{2}{*}{ Allele } & \multicolumn{2}{|c|}{ Okinawa } & \multicolumn{2}{|c|}{ Kerama } & \multicolumn{2}{|c|}{ Yaeyama } \\
\hline & & HED & ZAN & AKA & TOK & UGA & KUR \\
\hline \multirow[t]{5}{*}{$M d h$} & & $(20)$ & $(23)$ & (33) & $(49)$ & $(28)$ & (38) \\
\hline & 120 & 0.450 & 0.109 & 0.576 & 0.112 & 0.232 & 0.250 \\
\hline & 110 & 0.000 & 0.000 & 0.000 & 0.255 & 0.000 & 0.000 \\
\hline & 100 & 0.550 & 0.891 & 0.424 & 0.633 & 0.768 & 0.737 \\
\hline & 90 & 0.000 & 0.000 & 0.000 & 0.000 & 0.000 & 0.013 \\
\hline \multirow[t]{6}{*}{ Pgm } & & (18) & $(23)$ & (32) & $(47)$ & $(28)$ & (36) \\
\hline & 150 & 0.000 & 0.022 & 0.063 & 0.064 & 0.018 & 0.083 \\
\hline & 125 & 0.444 & 0.326 & 0.328 & 0.362 & 0.375 & 0.306 \\
\hline & 113 & 0.333 & 0.044 & 0.000 & 0.149 & 0.000 & 0.000 \\
\hline & 100 & 0.222 & 0.565 & 0.500 & 0.362 & 0.554 & 0.542 \\
\hline & 88 & 0.000 & 0.044 & 0.109 & 0.064 & 0.054 & 0.069 \\
\hline \multirow[t]{5}{*}{$H k$} & & (19) & $(23)$ & (32) & $(48)$ & $(28)$ & (37) \\
\hline & 100 & 0.579 & 0.565 & 0.609 & 0.656 & 0.554 & 0.392 \\
\hline & 92 & 0.316 & 0.348 & 0.344 & 0.292 & 0.446 & 0.405 \\
\hline & 85 & 0.105 & 0.065 & 0.047 & 0.052 & 0.000 & 0.189 \\
\hline & 69 & 0.000 & 0.022 & 0.000 & 0.000 & 0.000 & 0.014 \\
\hline \multirow[t]{6}{*}{$L t-1$} & & (19) & $(23)$ & (32) & $(47)$ & $(28)$ & (37) \\
\hline & 107 & 0.079 & 0.152 & 0.172 & 0.117 & 0.036 & 0.081 \\
\hline & 100 & 0.842 & 0.544 & 0.391 & 0.606 & 0.536 & 0.554 \\
\hline & 93 & 0.000 & 0.044 & 0.125 & 0.106 & 0.125 & 0.081 \\
\hline & 87 & 0.079 & 0.261 & 0.313 & 0.170 & 0.000 & 0.014 \\
\hline & 73 & 0.000 & 0.000 & 0.000 & 0.000 & 0.304 & 0.270 \\
\hline \multirow[t]{6}{*}{$L t-2$} & & (20) & (23) & (30) & $(50)$ & (29) & (39) \\
\hline & 175 & 0.000 & 0.000 & 0.000 & 0.000 & 0.035 & 0.103 \\
\hline & 150 & 0.225 & 0.239 & 0.250 & 0.300 & 0.259 & 0.577 \\
\hline & 115 & 0.000 & 0.000 & 0.000 & 0.000 & 0.069 & 0.013 \\
\hline & 100 & 0.650 & 0.674 & 0.750 & 0.650 & 0.552 & 0.269 \\
\hline & 70 & 0.125 & 0.087 & 0.000 & 0.050 & 0.086 & 0.039 \\
\hline
\end{tabular}


significantly higher for $A$. tenuis than for $S$. pistillata (2-sample $t$-test with Welch's correction, $\mathrm{p}<0.05)$. The latest settlement observed 69 and $51 \mathrm{~d}$ after gamete or planula release in the 3rd CP for A. tenuis and $S$. pistillata, respectively.

\section{Allozyme electrophoresis}

All 5 loci were polymorphic in Acropora tenuis (spawner), while 6 loci were polymorphic and 1 was monomorphic in Stylophora pistillata (brooder). The mean number of alleles per locus in each population ranged from 2.8 to 4.2 in A. tenuis, and from 1.6 to 2.4 in $S$. pistillata. The percentage of polymorphic loci $\left(\mathrm{P}_{95}\right)$ was 100.0 in A. tenuis and ranged from 42.9 to 71.4 in $S$. pistillata, indicating that genetic variability is greater in A. tenuis than in $S$. pistillata. The observed mean heterozygosity was lower or similar to the expected heterozygosity assuming Hardy-Weinberg equilibrium in both species (Table 1).

The ratio of the number of observed genotypes $\left(N_{\mathrm{G}}\right)$ to the number of individuals sampled $\left(N_{\mathrm{I}}\right)$ ranged from 0.94 to 1.00 in Acropora tenuis, and from 0.51 to 0.94 in Stylophora pistillata. The ratio of observed multilocus genotypic diversity $\left(G_{O}\right)$ to that expected under conditions of sexual reproduction $\left(G_{\mathrm{E}}\right)$ among collection sites ranged from 0.92 to 1.05 in $A$. tenuis, and from 0.44 to 0.92 in $S$. pistillata. The ratios of $N_{\mathrm{G}}: N_{\mathrm{I}}$ and $G_{\mathrm{O}}: G_{\mathrm{E}}$ in $A$. tenuis were close to $1.00(0.97 \pm 0.03$ and $0.99 \pm 0.05$; respectively, mean $\pm \mathrm{SD})$, while they were relatively low in $S$. pistillata $(0.67 \pm 0.18$ and $0.66 \pm 0.19$, respectively). In addition, there was no significant difference between the values for $G_{\mathrm{O}}$ and $G_{\mathrm{E}}$ in A. tenuis (unpaired $t$-test, $\mathrm{p}>0.05$ ) (Stoddart \& Taylor 1988). However, in $S$. pistillata, there was a significant difference between $G_{\mathrm{O}}$ and $G_{\mathrm{E}}$ in the Sesoko (SES), Aharen (AHA), and Sonai (SON) reefs ( $p<0.001,0.001$, and 0.01 , respectively). These results suggest that there is a high degree of sexual reproduction in A. tenuis and an incomplete reliance upon sexual reproduction in S. pistillata (Table 1).

The allele frequencies in Stylophora pistillata differed markedly among the 3 regions compared with Acropora tenuis (Tables 2 \& 3). In particular, in S. pistillata the frequency of $\mathrm{Hk}-2 * 48$ in the Yaeyama region was 1.000 , while it ranged from 0.000 to 0.122 in the Okinawa region. Additionally, the allele frequencies of $S$. pistillata also differed between reefs within each

Table 3. Stylophora pistillata. Allele frequency on 6 reefs in the Ryukyu Archipelago. Collection sites abbreviated as in Table 1. Values in parentheses: no. of individuals

\begin{tabular}{|c|c|c|c|c|c|c|c|}
\hline \multirow[t]{2}{*}{ Locus } & \multirow[t]{2}{*}{ Allele } & \multicolumn{2}{|c|}{ Okinawa } & \multicolumn{2}{|c|}{ Kerama } & \multicolumn{2}{|c|}{ Yaeyama } \\
\hline & & YAG & SES & SUN & AHA & UGA & $\mathrm{SON}$ \\
\hline \multirow[t]{2}{*}{$M d h$} & & (45) & (16) & $(37)$ & (49) & (18) & (14) \\
\hline & 100 & 1.000 & 1.000 & 1.000 & 1.000 & 1.000 & 1.000 \\
\hline \multirow[t]{4}{*}{ Pgm } & & (45) & (16) & (37) & (49) & (18) & (14) \\
\hline & 118 & 0.044 & 0.000 & 0.000 & 0.020 & 0.056 & 0.000 \\
\hline & 100 & 0.844 & 1.000 & 0.973 & 0.980 & 0.861 & 1.000 \\
\hline & 76 & 0.111 & 0.000 & 0.027 & 0.000 & 0.083 & 0.000 \\
\hline \multirow[t]{5}{*}{$H k-1$} & & $(45)$ & $(16)$ & (37) & (49) & (18) & (14) \\
\hline & 103 & 0.122 & 0.094 & 0.027 & 0.082 & 0.194 & 0.000 \\
\hline & 100 & 0.589 & 0.906 & 0.919 & 0.796 & 0.639 & 0.464 \\
\hline & 96 & 0.289 & 0.000 & 0.054 & 0.112 & 0.167 & 0.000 \\
\hline & 90 & 0.000 & 0.000 & 0.000 & 0.010 & 0.000 & 0.536 \\
\hline \multirow[t]{4}{*}{$H k-2$} & & $(45)$ & $(16)$ & $(37)$ & (49) & $(18)$ & (14) \\
\hline & 100 & 0.878 & 1.000 & 0.392 & 0.663 & 0.000 & 0.000 \\
\hline & 48 & 0.122 & 0.000 & 0.608 & 0.327 & 1.000 & 1.000 \\
\hline & 40 & 0.000 & 0.000 & 0.000 & 0.010 & 0.000 & 0.000 \\
\hline \multirow[t]{3}{*}{$L t$} & & $(45)$ & $(16)$ & (37) & (49) & (18) & (14) \\
\hline & 100 & 0.356 & 0.563 & 0.473 & 0.520 & 0.472 & 0.464 \\
\hline & 87 & 0.644 & 0.438 & 0.527 & 0.480 & 0.528 & 0.536 \\
\hline \multirow[t]{5}{*}{$L g g$} & & $(45)$ & (16) & (37) & (49) & (18) & (14) \\
\hline & 120 & 0.111 & 0.375 & 0.054 & 0.000 & 0.139 & 0.179 \\
\hline & 100 & 0.656 & 0.188 & 0.811 & 0.878 & 0.694 & 0.786 \\
\hline & 75 & 0.178 & 0.438 & 0.135 & 0.122 & 0.167 & 0.036 \\
\hline & 60 & 0.056 & 0.000 & 0.000 & 0.000 & 0.000 & 0.000 \\
\hline \multirow[t]{3}{*}{$V I$} & & (45) & (16) & (37) & (49) & (18) & (14) \\
\hline & 100 & 0.956 & 1.000 & 1.000 & 1.000 & 0.917 & 0.964 \\
\hline & 80 & 0.044 & 0.000 & 0.000 & 0.000 & 0.083 & 0.036 \\
\hline
\end{tabular}


region: e.g. $H k-1$ within the Yaeyama region and $H k-2$ within the Kerama region. In contrast, in A. tennis, although slightly high frequencies of $L t-1{ }^{*} 73$ were observed only in the Yaeyama region, frequencies of other loci were nearly similar among all reefs. For $S$. pistillata, the genetic distances (Nei 1978) among reefs

Table 4. Acropora tenuis. Nei's unbiased genetic distance (Nei 1978) between reefs. Collection sites abbreviated as in Table 1

\begin{tabular}{|lcccccc|}
\hline \multirow{2}{*}{$\begin{array}{l}\text { Popula- } \\
\text { tion }\end{array}$} & \multicolumn{2}{c}{ Okinawa } & \multicolumn{2}{c|}{ Kerama } & \multicolumn{2}{c|}{ Yaeyama } \\
& HED & ZAN & AKA & TOK & UGA & KUR \\
\hline HED & & & & & \\
ZAN & 0.098 & & & & \\
AKA & 0.100 & 0.086 & & & & \\
TOK & 0.055 & 0.028 & 0.091 & & & \\
UGA & 0.102 & 0.031 & 0.104 & 0.061 & & \\
KUR & 0.168 & 0.095 & 0.187 & 0.129 & 0.042 \\
& & & & & & \\
\hline
\end{tabular}

in all 3 regions were relatively greater than those of $A$. tenuis (0.028 to 0.187 in A. tenuis; 0.014 to 0.309 in $S$. pistillata; Tables 4 \& 5). Conversely, the genetic distances within reefs in each region were a little greater for A. tenuis than for $S$. pistillata (0.042 to 0.098 in $A$. tenuis; 0.014 to 0.060 in $S$. pistillata).

Table 5. Stylophora pistillata. Nei's unbiased genetic distance (Nei 1978) between reefs. Collection sites abbreviated as in Table 1

\begin{tabular}{|c|c|c|c|c|c|}
\hline \multirow{2}{*}{$\begin{array}{l}\text { Popula- } \\
\text { tion }\end{array}$} & \multicolumn{2}{|c|}{ Okinawa } & \multicolumn{2}{|c|}{ Kerama } & Yaeyama \\
\hline & YAG & SES & SUN & AHA & UGA SON \\
\hline \multicolumn{6}{|l|}{ YAG } \\
\hline SES & 0.060 & & & & \\
\hline SUN & 0.067 & 0.122 & & & \\
\hline AHA & 0.026 & 0.085 & 0.014 & & \\
\hline UGA & 0.167 & 0.259 & 0.039 & 0.095 & \\
\hline SON & 0.208 & 0.309 & 0.072 & 0.125 & 0.031 \\
\hline
\end{tabular}

Table 6. Acropora tenuis and Stylophora pistillata. D-values $\left(\left[H_{\mathrm{o}}-H_{\mathrm{e}}\right] / H_{\mathrm{e}}\right)$ indicating heterozygote deficit (negative number) or excess (positive number) for each reef. Significant deviations from Hardy-Weinberg proportions by conventional Monte Carlo method $={ }^{*} p<0.05,{ }^{* *} p<0.01,{ }^{* * *} p<0.001 ;$ nd: no data; $\mathrm{m}$ : monomorphic loci. Collection sites as in Table 1

\begin{tabular}{|c|c|c|c|c|c|c|c|c|c|}
\hline Population & $H k-1$ & $H k-2$ & Pgm & $M d h$ & $L t-1$ & $L t-2$ & $\operatorname{Lgg}$ & $V l$ & All loci \\
\hline \multicolumn{10}{|c|}{ Acropora tenuis } \\
\hline HED & -0.260 & nd & $-0.663^{*}$ & -0.212 & $-0.632^{* *}$ & $-0.905^{* * *}$ & nd & nd & -0.530 \\
\hline ZAN & -0.003 & nd & -0.179 & 0.097 & -0.235 & $-0.912^{* * *}$ & nd & nd & -0.277 \\
\hline AKA & -0.032 & nd & -0.263 & -0.267 & -0.127 & $-0.738^{* * *}$ & nd & nd & -0.251 \\
\hline TOK & -0.101 & nd & -0.376 & -0.226 & -0.090 & $-0.633^{* * *}$ & nd & nd & -0.285 \\
\hline UGA & 0.065 & nd & -0.234 & -0.311 & $-0.361^{* *}$ & $-0.559^{*}$ & nd & nd & -0.294 \\
\hline KUR & -0.216 & nd & $-0.408^{* *}$ & $-0.736^{* * *}$ & $-0.385^{*}$ & $-0.609^{* * *}$ & nd & nd & -0.446 \\
\hline \multicolumn{10}{|c|}{ Stylophora pistillata } \\
\hline YAG & $-0.366^{*}$ & $-0.488^{* *}$ & $-0.517^{* * *}$ & nd & -0.041 & nd & -0.160 & 0.035 & -0.260 \\
\hline SES & 0.069 & $\mathrm{~m}$ & $\mathrm{~m}$ & nd & -0.262 & nd & $0.244^{*}$ & $\mathrm{~m}$ & 0.028 \\
\hline SUN & 0.053 & -0.161 & 0.015 & nd & 0.123 & nd & -0.170 & $\mathrm{~m}$ & -0.041 \\
\hline AHA & -0.185 & -0.198 & $-1.000^{* * *}$ & nd & $0.336^{*}$ & nd & -0.248 & $\mathrm{~m}$ & -0.052 \\
\hline UGA & 0.129 & $\mathrm{~m}$ & -0.131 & nd & -0.025 & nd & -0.197 & 0.061 & -0.032 \\
\hline SON & $0.800^{* * *}$ & $\mathrm{~m}$ & $\mathrm{~m}$ & nd & -0.031 & nd & -0.606 & 0.000 & 0.121 \\
\hline
\end{tabular}

Table 7. Acropora tenuis and Stylophora pistillata. Genetic differentiation $\left(F_{\mathrm{ST}}\right)$ and gene flow $\left(N_{\mathrm{e}} m\right.$, average number of migration per generation) at 3 hierachical levels estimated for each pair of regions. Statistical significance calculated by 95 and 99 \% CI. O: Okinawa, K: Kerama; Y: Yaeyama; ${ }^{*} \mathrm{p}<0.05,{ }^{* *} \mathrm{p}<0.01$

\begin{tabular}{|c|c|c|c|c|c|c|c|c|}
\hline & \multicolumn{2}{|c|}{ K vs O } & \multicolumn{2}{|c|}{ Y vs O } & \multicolumn{2}{|c|}{ Y vs K } & \multicolumn{2}{|c|}{ Y vs K vs O } \\
\hline & $F_{\mathrm{ST}}$ & $N_{\mathrm{e}} m$ & $F_{\mathrm{ST}}$ & $N_{\mathrm{e}} m$ & $F_{\mathrm{ST}}$ & $N_{\mathrm{e}} m$ & $F_{\mathrm{ST}}$ & $N_{\mathrm{e}} m$ \\
\hline \multicolumn{9}{|c|}{ Acropora tenuis } \\
\hline All reefs & 0.022 & 11.1 & $0.042^{*}$ & 5.7 & $0.057^{* *}$ & 4.1 & $0.048^{* *}$ & 5.0 \\
\hline Reefs-region & 0.026 & 9.4 & 0.051 & 4.7 & $0.075^{* *}$ & 3.1 & $0.066^{* *}$ & 3.5 \\
\hline All regions & 0.011 & 22.5 & $0.026^{*}$ & 9.4 & $0.057^{* *}$ & 4.1 & 0.015 & 16.4 \\
\hline \multicolumn{9}{|c|}{ Stylophora pistillata } \\
\hline All reefs & $0.128^{* *}$ & 1.7 & $0.284^{* *}$ & 0.6 & 0.151 & 1.4 & $0.189^{* *}$ & 1.1 \\
\hline Reefs-region & $0.148^{* *}$ & 1.4 & $0.346^{* *}$ & 0.5 & $0.210^{*}$ & 0.9 & $0.215^{* *}$ & 0.9 \\
\hline All regions & $0.070^{* *}$ & 3.3 & $0.260^{*}$ & 0.7 & $0.160^{* *}$ & 1.3 & $0.142^{*}$ & 1.5 \\
\hline
\end{tabular}




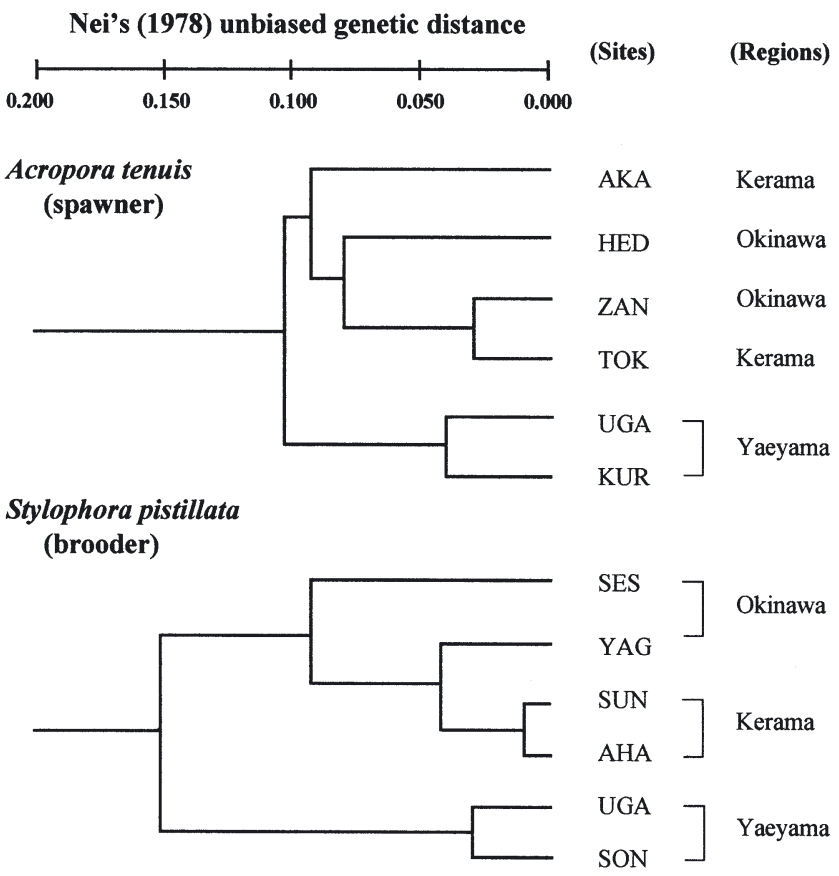

Fig. 3. Acropora tenuis and Stylophora pistillata. The UPGMA dendrogram showing relationship among populations based on Nei's unbiased genetic distance, $D$ (Nei 1978). Site abbreviations as in Table 1

Significant deviations from Hardy-Weinberg equilibrium were found at almost all polymorphic loci in both species $\left(\chi^{2}\right.$-test and conventional Monte Carlo method: Table 6). In particular, these deviations were observed at all reefs for the Lt-2 loci in Acropora tenuis. In Stylophora pistillata, significant deviations from Hardy-Weinberg equilibrium were relatively small in number compared to A. tenuis, but many monomorphic loci were observed.

The average number of migrants per generation $\left(N_{\mathrm{e}} m\right)$, calculated from $F_{\mathrm{ST}}$ (genetic differentiation, showed similar patterns among each pair of regions for both species $\left(N_{\mathrm{e}} m\right.$ : all regions $>$ all reefs $>$ reefsregion: Table 7). The $N_{\mathrm{e}} m$ values range from 3.1 to 22.5 and 0.5 to 3.3 in Acropora tenuis and Stylophora pistillata, respectively. In addition, they were relatively high in the Okinawa vs Kerama comparison, compared to other pairs of regions for both species. $F_{\mathrm{ST}}$ values were significantly different from zero in all pairs of regions, except in the Okinawa versus Kerama comparison for A. tenuis.

The UPGMA grouping of samples based on Nei's unbiased genetic distance (Nei 1978) also showed a similar pattern for both species. There were 2 cluster groups one for the Yaeyama reefs and a second cluster that included the Okinawa and Kerama reefs for both species (Fig. 3). In Acropora tenuis, the genetic distance for the Tokashika (TOK), Zanpa (ZAN), and Hedo (HED) reefs is in agreement with geographic distance in the Oki- nawa and Kerama regions, however, the Aka (AKA) reef in the Kerama region is genetically relatively distant compared to geographic distance. In Stylophora pistillata, the genetic distance for the Yagaji (YAG) reef in the Okinawa region was more similar to that for the 2 Kerama reefs than to the SES reef in the same region, in contrast to geographic distance.

\section{DISCUSSION}

The experiments in this study suggest that larval dispersal over a longer distance is more likely for Acropora tenuis than for Stylophora pistillata. The experiments revealed that: (1) the pre-competency periods of planulae after spawning (A. tenuis) or release (S. pistillata) were shorter for S. pistillata than for A. tenuis (a few hours and at least $4 \mathrm{~d}$, respectively); (2) the settlement peak after release occurred earlier for $S$. pistillata than for A. tenuis ( 1 and $7 \mathrm{~d}$ after release of larva or gametes, respectively); (3) the survival rate was higher for $A$. tenuis than for $S$. pistillata; (4) the competency period was longer for A. tenuis than for S. pistillata. These results suggest that the planulae of $S$. pistillata are likely to settle near the parent colonies if suitable substrate is available, as shown by Tioho et al. (2001) for the brooding coral Pocillopora damicornis. In contrast, the planulae of $A$. tenuis probably disperse away from the parent colonies. In addition to the dispersal potential of A. tenuis larvae, the Kuroshio Current, which flows from the southwest to the northeast in the Ryukyus, may promote long-distance dispersal.

Our results indicate that larval size or the presence of zooxanthellae are not necessarily related to the length of competency periods in scleractinian corals. The planulae of the brooder were generally large and already had zooxanthellae upon release from the maternal polyp, while the planulae of the spawner were generally small and did not have any zooxanthellae when they had fully developed (Harrison \& Wallace 1990). The planulae of Stylophora pistillata were larger than those of Acropora tenuis, but the competency period was longer for the latter than for the former. Isomura \& Nishihira (2001) studied the relationships between planula size and survivorship in 3 brooding coral species (Pocillopora damicornis, Seriatopora histrix, and Stylophora pistillata). They found size variation in planula released from the same colony during the same period, and showed that planulae survival increased with increasing size. This suggests that, within the same species, larger planulae can disperse longer distances than smaller ones. However, our results suggest that among species, the size of planulae does not predict dispersal potential. The planulae of $S$. pistillata contained zooxanthellae when 
they were released from maternal polyps, while the planulae of A. tenuis did not contain zooxanthellae when they had fully developed in seawater. However, $35 \mathrm{~d}$ after gamete release, planulae of $A$. tenuis, in seawater filtered through a $100 \mu \mathrm{m}$ mesh, did contain zooxanthellae, and furthermore, the percentage of planulae with zooxanthellae increased with time in the surviving larvae. These results show that the competency period is not determined by the presence of zooxanthellae in planulae, but by other factors. BenDavid-Zaslow \& Benayahu (1998) studied the competence, longevity, and caloric content of planulae from 6 species of soft corals: 3 with zooxanthellate planulae (Litophyton arboreum, Nephthea sp. and Xenia umbellata) and 3 with azooxanthellate planulae (Parerythropodium fulvum fulvum, Dendronephthya hemprichi, and Heteroxenia fuscescens). They found no significant differences between the competence or longevity of zooxanthellate and azooxanthellate planulae.

We found that the dispersal potential of larvae estimated from the laboratory experiments agreed well with the level of gene flow revealed by allozyme electrophoresis. The number of migrants per generation $\left(N_{\mathrm{e}} \mathrm{m}\right)$ across all 3 study regions was 3.9 to 10.9 times greater for Acropora tenuis ( $N_{\mathrm{e}}$ m: 3.5 to 16.4) than for Stylophora pistillata ( $N_{\mathrm{e}} \mathrm{m:} 0.9$ to 1.5 ). In addition, Nei's unbiased genetic distances (Nei 1978) among reefs for $S$. pistillata were relatively greater than those for $A$. tenuis. The $N_{\mathrm{e}} m$ and genetic distance data suggest that gene flow via larval dispersal is highly restricted in S. pistillata. These results are in agreement with the results of the larval experiments; i.e. planulae of $S$. pistillata (brooder) tended to settle earlier than those of $A$. tenuis (spawner). Similarly, in other marine invertebrates, there are several reports showing agreement between genetic data and larval duration. For example, Benzie \& Stoddart (1992; Acanthaster planci), Williams \& Benzie (1993; Linckia laevigata), and Benzie \& Williams (1997; Tridacna maxima) showed that invertebrates with long larval periods had high levels of gene flow, while Foltz et al. (1996; Leptasterias epichrola) and Johnson \& Threlfall (1987; Coscinasterias calamaria) showed that invertebrates without a dispersal larval stage had a highly restricted gene flow.

Our allozyme electrophoresis results support the hypothesis that coral populations in the Kerama region are the larval source for the recovery of coral populations in the Okinawa Islands following the 1998 massbleaching (Loya et al. 2001). Although the coral populations in the Okinawa Islands, particularly those of branching species, declined severely during the 1998 mass-bleaching event (Loya et al. 2001), the Kerama and Yaeyama Islands maintained healthy coral communities on many reefs (Taniguchi \& Iwao 2000, Ministry of the Environment of Japan 2002). In the present study, in both species, $N_{\mathrm{e}} m$ and genetic distances were relatively high and small, respectively, between the Okinawa and Kerama regions compared to the Yaeyama region. However, there were a few exceptions. The UPGMA dendrogram based on Nei's genetic distance, the TOK reef in the Kerama region and the ZAN reef in the Okinawa region formed a small cluster, while the Aka reef in the Kerama region and the HED reef in the Okinawa region were relatively distant from the cluster of the TOK and ZAN reefs for Acropora tenuis. Geographic distances among reefs in the Okinawa and Kerama regions were small except for the HED reef (see Fig. 1). Since gene flows $\left(N_{\mathrm{e}} m\right)$ are large enough to prevent divergence (Table 7), there may be other factors (i.e. localized selection) influencing the AKA reef. In Stylophora pistillata, the small cluster of Kerama reefs (Sun: SUN and AHA) was close to the YAG reef in the Okinawa region, but relatively distant from the SES reef, even in the same region. For the SES reef we had only a small number of samples (16), and we found a positive correlation for genetic distance against geographic distance $(p<0.01$, data not shown). Therefore the SES results may be an artifact of small sample size. Except for a few reefs, there is probably sufficient genetic exchange among reefs in the Kerama and Okinawa regions in both species. In addition, the values of $N_{\mathrm{e}} \mathrm{m}$ between the Okinawa and Kerama regions were lower for $S$. pistillata (1.4 to 3.3) than for A. tenuis (9.4 to 22.5). These results indicate that fewer $S$. pistillata larvae may disperse between these 2 regions than those of $A$. tenuis; the results also suggested that the speed of recovery of $S$. pistillata in the Okinawa region may be slower than that of $A$. tenuis.

Acknowledgements. We would like to thank T. Kuwamura, Y. Nakashima, M. Toda, C. Fiedler and H. Hata for their comments and suggestions. We are indebted to the staff of Sesoko Station, Tropical Biosphere Research Center, University of the Ryukyus; the staff of the International Coral Reef Research and Monitoring Center; the staff of the Akajima Marine Science Laboratory; and the staff of National Okinawa Youth Center, Yaeyama Marine Park Research Station. Thanks are due to T. Yamamoto, Y. Nozawa, M. Yoshimoto and many students in TBRC for their encouragement, help and advice. We also thank A. Iwase for his computer program for multilocus genotypic diversity. We are grateful to 4 anonymous reviewers for valuable comments and suggestions. This study was partly supported by grants from the Japanese Ministry of Education, Science, Sports and Culture (Nos. 12640619 and 14205071-7), and from the Sumitomo Foundation (No. 993212).

\section{LITERATURE CITED}

Adjeroud M, Tsuchiya M (1999) Genetic variation and clonal structure in the scleractinian coral Pocillopora damicornis in the Ryukyu Archipelago, southern Japan. Mar Biol 134: $753-760$ 
Atoda K (1947) The larva and postlarval development of some reef-building corals. II. Stylophora pistillata (Esper). Sci Rep Tohoku Univ Fourth 18:48-64

Ayre DJ, Hughes TP (2000) Genotypic diversity and gene flow in brooding and spawning corals along the Great Barrier Reef, Australia. Evolution 54:(5)1590-1605

Babcock RC (1984) Reproduction and distribution of two species of Goniastrea (Scleractinia) from the Great Barrier Reef Province. Coral Reefs 2:187-195

Babcock RC, Heyward AJ (1986) Larval development of certain gamete-spawning scleractinian corals. Coral Reefs 5: 111-116

Babcock RC, Bull GD, Harrison PL, Heyward AJ, Oliver JK, Wallace CC, Willis BL (1986) Synchronous spawnings of 105 scleractinian coral species on the Great Barrier Reef. Mar Biol 90:379-394

Ben-David-Zaslow RBD, Benayahu Y (1998) Competence and longevity in planulae of several species of soft corals. Mar Ecol Prog Ser 163:235-243

Benzie JAH, Stoddart JA (1992) The genetic structure of crown-of-thorns starfish (Acanthaster planci) in Australia. Mar Biol 112:631-639

Benzie JAH, Williams ST (1997) Genetic structure of giant clam (Tridacna maxima) populations in the west Pacific is not consistent with dispersal by present-day ocean currents. Evolution 51(3):768-783

Foltz DW, Breaux JP, Campagnaro EL, Herke SW, Himel AE, Hrincevich AW, Tamplim JW, Stickle WB (1996) Limited morphological differences between genetically identified cryptic species within the Leptasterias species complex (Echinodermata: Asteroidea). Can J Zool 74:1275-1283

Harii S, Kayanne H, Takigawa H, Hayashibara T, Yamamoto $M$ (2002) Larval survivorship, competency periods and settlement of two brooding corals, Heliopora coerulea and Pocillopora damicornis. Coral Reefs 121:39-46

Harrigan JF (1972) The planula larvae of Pocillopora damicornis; lunar periodicity of swarming and substratum selection behavior. University of Hawaii, Honolulu

Harrison PL, Wallace CC (1990) Reproduction, dispersal and recruitment of scleractinian corals. In: Dubinsky Z (ed) Ecosystems of the world, Vol 25. Coral reefs. Elsevier, New York, p 133-207

Heyward AJ, Babcock RC (1986) Self- and cross-fertilization in scleractinian corals. Mar Biol 90:191-195

Hillis DM, Moritz C, Barbara KM (1996) Molecular systematics. Sinauer Associates, Sunderland, MA

Hodgson G (1985) Abundance and distribution of planktonic coral larvae in Kaneohe Bay, Oahu, Hawaii. Mar Ecol Prog Ser 26:61-71

Isomura N, Nishihira M (2001) Size variation of planulae and its effect on the lifetime of planulae in three pocilloporid corals. Coral Reefs 20:309-315

Johnson MS, Threlfall TJ (1987) Fissiparity and population

Editorial responsibility: Otto Kinne (Editor),

Oldendorf/Luhe, Germany genetics of Coscinasterias calamaria. Mar Biol 93:517-525

Loya Y, Sakai K, Yamazato K, Nakano Y, Sambali H, Woesik RV (2001) Coral bleaching: the winners and losers. Ecol Lett 4:122-131

Ministry of the Environment of Japan (2002) Report of the International Coral Reef Research and Monitoring Center. International Coral Reef Research and Monitoring Center, Ishigaki, p 13-34 (in japanese)

Morse ANC, Iwao K, Baba M, Shimoike K, Hayashibara T, Omori M (1996) An ancient chemosensory mechanism brings new life to coral reefs. Biol Bull 191:149-154

Morse DE, Morse ENC (1991) Enzymatic characterization of the inducer recognized by Agaricia humilis (scleractinian coral) larvae. Biol Bull 181:104-122

Nei M (1978) Estimation of average heterozygosity and genetic distance from a small number of individuals. Genetics 89:583-190

Richmond RH (1987a) Energetics, competency, and longdistance dispersal of planula larvae of the coral Pocillopora damicornis. Mar Biol 93:527-533

Richmond RH (1987b) Energetic relationships and biogeographical differences among fecundity, growth and reproduction in the reef coral Pocillopora damicornis. Bull Mar Sci 42(2):594-604

Sakai K (1997) Gametogenesis, spawning, and planulabrooding by the reef coral Goniastrea aspera (Scleractinia) in Okinawa, Japan. Mar Ecol Prog Ser 151:67-72

Selander RK, Smith MH, Yank SY, Johnston WE, Gentry JR (1971) Biochemical polymorphism and systematics in the genus Peromyscus. I. Variation in the old-field mouse (Peromyscus polionotus). Stud Genet 7103:49-90

Stoddart JA (1984) Genetic differentiation amongst populations of the coral Pocillopora damicornis off southwestern Australia. Coral Reefs 3:149-156

Stoddart JA, Taylor JF (1988) Genotypic diversity: estimation and prediction in samples. Genetics 118:705-711

Taniguchi $\mathrm{H}$, Iwao K (2000) Change of coral number and density in Aka Island. Rep Akajima Mar Sci Lab 11:22-23 (in Japanese)

Tioho H, Tokeshi M, Nojima S (2001) Experimental analysis of recruitment in a scleractinian coral at high latitude. Mar Ecol Prog Ser 213:79-86

Weir BS, Cockerham CC (1984) Estimating F-statistics for the analysis of population structure. Evolution 41:1358-1370

Williams ST, Benzie JAH (1993) Genetic consequences of long larval life in the starfish Linckia laevigata (Echinodermata: Asteroidea) on the Great Barrier Reef. Mar Biol 117:71-77

Wilson JR, Harrison PL (1998) Settlement-competency periods of larvae of three species of scleractinian corals. Mar Biol 131:339-345

Wright S (1969) The evolution and genetics of populations. University of Chicago Press, Chicago

Submitted: December 11, 2002; Accepted: March 11, 2003

Proofs received from author(s): June 24, 2003 